\title{
ANALISIS PENERAPAN PROSEDUR PEMOTONGAN, PENYETORAN DAN PELAPORAN PAJAK PENGHASILAN PASAL 23 ATAS JASA PADA PT. DANA TABUNGAN DAN ASURANSI PEGAWAI NEGERI (PERSERO) KANTOR CABANG MANADO
}

\author{
Nadia K. Wiyadi ${ }^{1}$, Jullie J. Sondakh ${ }^{2}$, Sherly Pinatik ${ }^{3}$ \\ ${ }^{1,2,3}$ Jurusan Akuntansi, Fakultas Ekonomi dan Bisnis, Universitas Sam Ratulangi, Jl. Kampus Bahu, Manado, \\ 95115, Indonesia \\ E-mail : nadiakusumah97@gmail.com
}

\begin{abstract}
Tax is one of the revenue sources of the largest country in Indonesian. A function of tax namely can be used to finance all government spending, in terms of development and activities that pertaining to the interests and prosperity the country. One source of country revenues is income tax. This study aims to analysis the application of the procedure of cutting, payment and reporting Income Tax Article 23 for services to PT. Savings Accounts and Insurance Civil Servants (Persero) Branch Offices Manado is it in accordance with the law number 36/2008 who set about income tax in Indonesian. The method of analysis that used in this research analytics object, cutting the calculation and payment and reporting and analysis. And the kind of research used in this research was the qualitative study descriptive. The results of research obtained (1) Objects income tax article 23 all have applied in accordance with the provisions the act of income tax article 23 (2) The calculation when tested, there is some object which had not yet in accordance with the provisions of article 23 (3) The process of payment and reporting income tax is in line with provisions of article 23. Keywords : Analysis, Procedure, Income Tax, Services
\end{abstract}

\section{PENDAHULUAN}

Pajak merupakan salah satu sumber penerimaan negara terbesar di Indonesia. Fungsi dari pajak yaitu digunakan untuk pembiayaan pengeluaran pemerintah seperti pembangunan yang penting untuk kesejahteraan negara. Sebagai salah satu sumber penerimaan negara, penting bagi pemerintah untuk meningkatkan kesejahteraan dan kemakmuran masyarakat Indonesia. Pemerintah pun meningkatkan berbagai kebijakan dibidang perpajakan, seperti kebijakan yang sudah ada ditinjau kembali dan diberlakukan dengan tegas.

Badan Usaha Milik Negara (BUMN) di Indonesia yang bergerak dibidang asuransi Tabungan Hari Tua (THT) dan dana pensiun pegawai negeri menjadi subjek pajak dalam penelitian. Perusahaan dibentuk dengan Undang-Undang Republik Indonesia Nomor 11 Tahun 1969 tentang Pensiun Pegawai dan Pensiun Janda/Duda Pegawai, Undang-Undang Republik Indonesia Nomor 11 Tahun 1992 tentang Dana Pensiun dan Undang-Undang Republik Indonesia Nomor 40 Tahun 2004 tentang Sistem Jaminan Sosial Nasional. Dengan adanya pedoman perpajakan maka dapat menjadi acuan dan menjadi petunjuk pelaksanaan perusahaan mengenai sistem perpajakan serta dalam rangka mewujudkan prinsip-prinsip Good Corporate Governance (GCG).

Jika sebuah perusahaan telah melakukan akuntansi perpajakan yang sudah sesuai dengan Undang-Undang Perpajakan yang berlaku. Hal tersebut dapat menjelaskan bahwa Wajib Pajak orang pribadi maupun badan telah taat dengan aturan perpajakan yang diberlakukan oleh pemerintah melalui Direktorat Jenderal Pajak (DJP) dibawah Kementerian Keuangan Republik Indonesia. 


\section{TINJAUAN PUSTAKA}

Pengertian Akuntansi. Akuntansi adalah ilmu dalam mencatat, menggolongkan dan menganalisis seluruh transaksi keuangan dalam suatu perusahaan menjadi sebuah informasi yang dapat membantu perusahaan dalam pengambilan keputusan.

\section{Dasar-Dasar Perpajakan}

Pengertian. Pajak adalah iuran wajib masyarakat kepada negara berdasarkan undangundang, untuk pembiayaan pengeluaran pemerintah seperti pembangunan yang penting untuk kesejahteraan negara.

Subjek Pajak. Subjek pajak dikenakan atas penghasilan yang diterima atau diperoleh dalam tahun pajak.

Objek Pajak. Objek pajak dikenakan atas penghasilan yaitu setiap tambahan kemampuan ekonomis yang diterima atau diperoleh baik yang berasal Indonesia maupun dari luar Indonesia.

Dasar Hukum Pajak Penghasilan. Adapun dasar hukum yang mengatur mengenai Pajak Penghasilan yaitu Undang-Undang Nomor 36 Tahun 2008.

\section{Pajak Penghasilan Pasal 23}

Pengertian. Pajak Penghasilan Pasal 23 adalah transaksi pembayaran dividen, bunga, royalti, hadiah, penghargaan, bonus dan sejenisnya selain yang telah diipotong PPh Pasal 21, sewa dan penghasilan lain sehubungan dengan penggunaan harta. (Lubis, 2015 : 20)

Pemotong Pajak. Pemotong Pajak Penghasilan Pasal 23 adalah pihak-pihak yang membayarkan penghasilan.

Objek Pemotongan. Penghasilan yang dipotong Pajak Penghasilan Pasal 23 adalah:

1. Dividen.

2. Bunga termasuk premium, diskonto dan imbalan.

3. Royalti.

4. Hadiah, penghargaan, bonus dan sejenisnya.

5. Sewa kecuali sewa tanah dan/atau bangunan.

6. Imbalan sehubungan dengan jasa teknik, jasa manajemen, jasa konstruksi, jasa konsultan dan jasa lain.

\section{Tarif Pemotongan}

1. Tarif $15 \%$ dari jumlah bruto atas:
a. Dividen.
b. Bunga termasuk premium, diskonto dan imbalan.
c. Royalti.
d. Hadiah, penghargaan, bonus dan sejenisnya.

2. Tarif $2 \%$ dari jumlah bruto tidak termasuk Pajak Pertambahan Nilai atas:

a. Sewa kecuali sewa tanah dan/atau bangunan.

b. Imbalan berhubungan dengan jasa teknik, jasa manajemen, jasa konstruksi, jasa konsultan dan jasa.

\section{Prosedur Pemotongan Pajak Penghasilan Pasal 23}

Pihak Pemotong. Melalui Withholding System pihak pemotong adalah pihak-pihak yang membayarkan penghasilan. Pihak ketiga adalah pihak bendahara yang bertanggungjawab atas kewajiban perpajakannya. Hal ini membuat pihak bendahara yang bertanggungjawab harus mengisi segala data secara benar, jelas dan lengkap.

Prosedur Pemotongan. Prosedur dalam pemotongan Pajak Penghasilan Pasal 23 yaitu sebagai berikut:

1. Pihak Bendahara menyiapkan dan mengisi Bukti Pemotongan dengan PPh yang dipotong sesuai dengan tarif pemotongan. 
2. Pihak Bendahara menyiapkan dan mengisi Daftar Bukti Pemotongan berdasarkan Bukti Pemotongan dalam masa pajaknya dan dijumlahkan.

3. Pihak Bendahara membawa Bukti Pemotongan dan Daftar Bukti Pemotongan untuk ditandatangani oleh Kepala Bidang Kas.

4. Pihak Bendahara memberikan lembar ke-1 dari Bukti Pemotongan penyedia jasa sebagai bukti telah dilakukan pemotongan.

Dalam menyiapkan bukti pemotongan, $\mathrm{PPh}$ yang dipotong harus sesuai dengan tarif pemotongan Pajak Penghasilan Pasal 23. Dimana tarif yang dikenakan untuk penyedia jasa yang memiliki NPWP sebesar 2\% dan 4\% yang tidak memiliki NPWP. Untuk Bukti Pemotongan lembar ke-1 untuk Wajib Pajak, lembar ke-2 untuk Kantor Pelayanan Pajak dan lembar ke-3 untuk Pemotong Pajak

Prosedur Penyetoran. Prosedur dalam penyetoran Pajak Penghasilan Pasal 23 yaitu sebagai berikut:

1. Pihak Bendahara menyiapkan dan mengisi Surat Setoran Pajak (SSP) secara benar, jelas dan lengkap.

2. Pihak Bendahara membawa Surat Setoran Pajak (SSP) dan Daftar Bukti Pemotongan untuk dilakukan penyetoran ke Bank yang ditunjuk oleh Menteri Keuangan.

3. Pihak Bank yang ditunjuk oleh Menteri Keuangan akan memberikan Bukti Penyetoran sebagai bukti bahwa pihak pemotong telah melakukan penyetoran.

Untuk Surat Setoran Pajak (SSP) lembar ke-1 untuk Arsip Wajib Pajak, lembar ke-2 untuk Kantor Pelayanan Perbendaharaan Negara, lembar ke-3 untuk dilaporkan ke Kantor Pelayanan Pajak dan lembar ke-4 untuk Bank Persepsi/Kantor Pos dan Giro. Dalam hal penyetoran Pajak Penghasilan Pasal 23 jangka waktu yang telah ditetapkan oleh Pemerintah harus disetor paling lama tanggal 10 bulan berikutnya.

Prosedur Pelaporan. Prosedur dalam pelaporan Pajak Penghasilan Pasal 23 yaitu sebagai berikut:

1. Pihak Bendahara menyiapkan dan mengisi Surat Pemberitahuan (SPT) secara benar, jelas dan lengkap sesuai dengan Surat Setoran Pajak (SSP).

2. Pihak Bendahara melakukan pelaporan ke Kantor Pelayanan Pajak (KPP) dengan melampirkan Surat Pemberitahuan (SPT), Surat Setoran Pajak (SSP), Daftar Bukti Pemotongan dan Bukti Pemotongan.

3. Pihak Kantor Pelayanan Pajak (KPP) akan memberikan Bukti Pelaporan sebagai bukti bahwa pihak pemotong telah melakukan pelaporan.

Dalam hal pelaporan Pajak Penghasilan Pasal 23 jangka waktu yang telah ditetapkan oleh Pemerintah harus disetor paling lama tanggal 20 bulan berikutnya.

\section{METODE PENELITIAN}

Jenis Penelitian. Jenis penelitian adalah penelitian kualitatif deskriptif. Digunakan sebagai acuan dalam penelitian, dengan cara yang efektif untuk mendapatkan hasil penelitian, dengan demikian penelitian ini dilakukan untuk menyajikan fakta penerapan prosedur pemotongan, penyetoran dan pelaporan Pajak Penghasilan Pasal 23 atas jasa.

Tempat dan Waktu Penelitian. Tempat penelitian dilakukan pada PT. Dana Tabungan dan Asuransi Pegawai Negeri (Persero) Kantor Cabang Manado yang beralamat di Jalan Ahmad Yani Nomor 7, Sario Tumpaan, Sario, Kota Manado, Sulawesi Utara. Waktu penelitian dimulai dari bulan Juni tahun 2018 sampai dengan selesai.

Prosedur Penelitian. Mengumpulkan data melalui wawancara secara langsung dalam hal ini tanya jawab dengan pegawai yang bertanggung jawab, mengumpulkan data melalui observasi lapangan dalam hal ini pengamatan secara langsung dan pencatatan secara sistematis terhadap objek, mengumpulkan data melalui studi dokumentasi, menganalisis data, mengolah data dan membuat hasil penelitian. 
Sumber Data. Sumber data yang digunakan adalah data primer. Data primer didapat dari data dan informasi yang relevan dengan penelitian, melalui wawancara, observasi dan studi dokumentasi.

Teknik Pengumpulan Data. Teknik pengumpulan data yang akan dilakukan dalam penelitian ini adalah dengan cara sebagai berikut: (1) Metode wawancara secara langsung; (2) Metode observasi lapangan; dan (3) Studi dokumentasi.

Teknik Analisis Data. Teknik analisis data yang digunakan dalam penelitian ini adalah Analisis Objek, Analisis Perhitungan dan Pemotongan dan Analisis Penyetoran dan Pelaporan. Analisis Objek bertujuan untuk mendapatkan suatu kesimpulan mengenai apakah seluruh objek Pajak Penghasilan Pasal 23 yang berlaku telah dilakukan pengenaan atau belum. Analisis Perhitungan dan Pemotongan bertujuan untuk mengetahui apakah cara perhitungan dan pemotongan yang dilakukan sudah sesuai dengan Undang-Undang Perpajakan yang berlaku. Analisis Penyetoran dan Pelaporan bertujuan untuk mendapatkan suatu kesimpulan mengenai apakah seluruh transaksi yang telah dilakukan perhitungan dan pemotongan selama Tahun 2017 telah melakukan penyetoran dan pelaporan atau belum, kemudian dibandingkan sesuai dengan Undang-Undang Perpajakan yang berlaku.

\section{HASIL ANALISIS DAN PEMBAHASAN}

4.1. Hasil Analisis

Objek Pajak. Pemungutan Pajak Penghasilan Pasal 23 atas jasa-jasa pada Tahun 2017, sebagai berikut:

1. Jasa Sewa Lapangan Futsal, alasan dilakukannya pemungutan terhadap jasa tersebut dikarenakan Jasa Sewa Lapangan Futsal masuk dalam objek pajak yaitu sewa yang digunakan oleh perusahaan.

2. Jasa Perbaikan AC, alasan dilakukannya pemungutan terhadap jasa tersebut dikarenakan Jasa Perbaikan AC masuk dalam objek pajak yaitu jasa lain yang digunakan oleh perusahaan.

3. Jasa Pendidikan dan Pelatihan, alasan dilakukannya pemungutan terhadap jasa tersebut dikarenakan Jasa Pendidikan dan Pelatihan masuk dalam objek pajak yaitu kegiatan yang dilakukan oleh perusahaan.

4. Jasa Sewa Kursi dan Mobil, alasan dilakukannya pemungutan terhadap jasa tersebut dikarenakan Jasa Sewa Kursi dan Mobil masuk dalam objek pajak yaitu sewa yang digunakan oleh perusahaan.

5. Jasa Petugas Alih Daya PKS, alasan dilakukannya pemungutan terhadap jasa tersebut dikarenakan Jasa Petugas Alih Daya PKS masuk dalam objek pajak yaitu jasa lain yang digunakan oleh perusahaan dalam hal ini petugas keamanan, kebersihan dan sopir.

6. Jasa Catering, alasan dilakukannya pemungutan terhadap jasa tersebut dikarenakan Jasa Catering masuk dalam objek pajak yaitu jasa lain yang digunakan oleh perusahaan.

7. Jasa Perbaikan Kendaraan, alasan dilakukannya pemungutan terhadap jasa tersebut dikarenakan Jasa Perbaikan Kendaraan masuk dalam objek pajak yaitu jasa lain yang digunakan oleh perusahaan.

8. Jasa Perbaikan Pintu Gedung Kantor, alasan dilakukannya pemungutan terhadap jasa tersebut dikarenakan Jasa Perbaikan Pintu Gedung Kantor masuk dalam objek pajak yaitu jasa lain yang digunakan oleh perusahaan.

9. Jasa Sosialisasi Media, alasan dilakukannya pemungutan terhadap jasa tersebut dikarenakan Jasa Sosialisasi Media masuk dalam objek pajak yaitu kegiatan yang dilakukan di perusahaan.

10. Jasa Penyedia Tenaga Kerja/Tenaga Ahli, alasan dilakukannya pemungutan terhadap jasa tersebut dikarenakan Jasa Penyedia Tenaga Kerja/Tenaga Ahli masuk dalam objek pajak 
yaitu jasa lain yang digunakan oleh perusahaan dengan perusahaan penyedia tenaga kerja/tenaga ahli berdasarkan perjanjian.

11. Jasa Penyedia Tempat, alasan dilakukannya pemungutan terhadap jasa tersebut dikarenakan Jasa Penyedia Tempat masuk dalam objek pajak yaitu jasa lain yang digunakan oleh perusahaan.

Alasan perusahaan melakukan pemungutan terhadap 11 (sebelas) jasa tersebut dikarenakan 11 (sebelas) jasa tersebut masuk dalam objek penghasilan yang dipotong Pajak Penghasilan Pasal 23.

Perhitungan dan Pemotongan. Perhitungan yang dilakukan oleh perusahaan terdiri dari 2 (dua) perhitungan yaitu dilakukan dengan perhitungan sebesar $2 \%$ dan perhitungan sebesar $4 \%$. Dimana perusahaan melakukan perhitungan sebesar $2 \%$ apabila penyedia jasa memiliki NPWP (Nomor Pokok Wajib Pajak), sedangkan perusahaan melakukan perhitungan sebesar 4\% apabila penyedia jasa tidak memiliki NPWP (Nomor Pokok Wajib Pajak). Pihak Pemotong yang diberikan wewenang oleh perusahaan adalah pihak bendahara yang bertanggungjawab atas kewajiban perpajakannya, maka dalam hal ini pihak bendahara harus mengisi segala data secara benar, jelas dan lengkap.

Berikut prosedur perhitungan dan pemotongan yang dilakukan oleh perusahaan:

1. Pihak Bendahara menyiapkan dan mengisi Bukti Pemotongan dengan PPh yang dipotong sesuai dengan tarif pemotongan.

2. Pihak Bendahara menyiapkan dan mengisi Daftar Bukti Pemotongan berdasarkan Bukti Pemotongan dalam masa pajaknya dan dijumlahkan.

3. Pihak Bendahara membawa Bukti Pemotongan dan Daftar Bukti Pemotongan untuk ditandatangani oleh Kepala Bidang Kas.

4. Pihak Bendahara memberikan lembar ke-1 dari Bukti Pemotongan kepada penyedia jasa sebagai bukti telah dilakukan pemotongan. Daftar Bukti Pemotongan akan dijadikan bukti dalam proses penyetoran.

\section{Penyetoran dan Pelaporan}

Penyetoran. Penyetoran yang dilakukan oleh perusahaan menggunakan beberapa dokumen yang diperlukan dalam penyetoran, adapun prosedur dan beberapa dokumen yang diperlukan dalam penyetoran yaitu sebagai berikut:

1. Pihak Bendahara mengisi Surat Setoran Elektronik (Electronic Billing System) secara benar, jelas dan lengkap dan mencetak kode billing. Setelah diterbitkan Modul Penerimaan Negara Generasi Kedua (MPN G2), perusahaan tidak lagi menggunakan Surat Setoran Pajak (SSP) manual dalam menyetorkan utang pajak. Perusahaan menggunakan Surat Setoran Elektronik (Electronic Billing System), Modul Penerimaan Negara Generasi Kedua (MPN G2) adalah sistem penerimaan negara yang menggunakan surat setoran elektronik yang berdasarkan sistem billing.

2. Pihak Bendahara membawa cetakan kode billing berdasarkan Surat Setoran Elektronik (Electronic Billing System) yang telah diisi secara benar, jelas dan lengkap dan Daftar Bukti Pemotongan untuk dilakukan penyetoran ke Bank BRI yang telah ditunjuk oleh Menteri Keuangan. Pihak Bank BRI yang ditunjuk oleh Menteri Keuangan akan memberikan Bukti Penerimaan Negara (BPN) sebagai bukti bahwa pihak pemotong telah melakukan penyetoran.

3. Bukti Penerimaan Negara (BPN) yang diberikan oleh pihak Bank BRI akan menjadi bukti perusahaan ketika akan melakukan pelaporan dan bukti telah melakukan penyetoran.

Proses penyetoran terjadi pada setiap bulannya. Dimana dalam penyetoran perbulannya perusahaan telah menyetorkan utang pajak tepat waktu. Hal ini dapat dilihat dari tanggal penyetorannya yang tidak melebihi dari tanggal 10 bulan berikutnya. 
Pelaporan. Pelaporan yang dilakukan oleh perusahaan menggunakan beberapa dokumen yang diperlukan dalam pelaporan, adapun prosedur dan beberapa dokumen yang diperlukan dalam pelaporan yaitu sebagai berikut:

1. Pihak Bendahara menyiapkan dan mengisi Surat Pemberitahuan (SPT) sesuai dengan Surat Setoran Elektronik (Electronic Billing System) yang telah diisi secara benar, jelas dan lengkap. Perusahaan dalam melakukan pelaporan pajak terutangnya masih menggunakan Surat Pemberitahuan (SPT) dengan bentuk formulir kertas (hardcopy).

2. Pihak Bendahara melakukan pelaporan ke Kantor Pelayanan Pajak (KPP) dengan melampirkan Surat Pemberitahuan (SPT), Surat Setoran Elektronik (Electronic Billing System) dengan melampirkan kode billing, Daftar Bukti Pemotongan dan Bukti Pemotongan.

3. Pihak Kantor Pelayanan Pajak (KPP) akan memberikan Bukti Pelaporan berupa Bukti Penerimaan Surat (BPS) sebagai bukti bahwa pihak pemotong telah melakukan pelaporan.

Proses pelaporan terjadi pada setiap bulannya. Dimana dalam pelaporan perbulannya perusahaan selaku pihak yang memotong telah melaporkan utang pajak tepat waktu. Hal ini dapat dilihat dari tanggal pelaporannya yang tidak melebihi dari tanggal 20 bulan berikutnya.

\subsection{Pembahasan}

Analisis Objek Pajak. Berdasarkan hasil penelitian pada bagian sebelumnya objekobjek pajak yang diakui oleh perusahaan selama Tahun 2017, telah melakukan pemungutan. Setelah ditelusuri lebih lanjut terhadap jasa-jasa yang telah dilakukan pemungutan untuk Tahun 2017 dan dibandingkan dengan ketentuan dalam Pasal 23 Undang-Undang Pajak Penghasilan. Maka dapat disimpulkan sebagai berikut seluruh jasa yang berkenaan dengan Pajak Penghasilan Pasal 23 telah dilakukan pemungutan dan sesuai dengan objek pemotongan, yaitu sebagai berikut:

1. Jasa Perbaikan AC, jasa ini merupakan pembayaran atas pemakaian jasa pada pihak penyedia jasa meliputi perawatan/perbaikan/pemeliharaan AC. Saat ini apabila dikaitkan dengan Pajak Penghasilan Pasal 23, maka dapat dikatakan telah memenuhi syarat.

2. Jasa Perbaikan Kendaraan, jasa ini merupakan pembayaran atas pemakaian jasa pada pihak penyedia jasa meliputi perawatan/perbaikan/pemeliharaan kendaraan. Saat ini apabila dikaitkan dengan Pajak Penghasilan Pasal 23, maka dapat dikatakan telah memenuhi syarat.

3. Jasa Penyedia Tenaga Kerja/Tenaga Ahli, jasa ini merupakan pembayaran atas pemakaian jasa pada pihak penyedia jasa. Pembayaran didasarkan atas perjanjian dengan perusahaan lain untuk menyediakan jasa. Saat ini apabila dikaitkan dengan Pajak Penghasilan Pasal 23, maka dapat dikatakan telah memenuhi syarat.

Analisis Perhitungan dan Pemotongan. Berdasarkan hasil perhitungan pada bagian sebelumnya terdapat kesalahan dalam perhitungan Pajak Penghasilan Pasal 23 selama Tahun 2017. Dimana ada penyedia jasa yang memiliki Nomor Pokok Wajib Pajak (NPWP) namun dikenakan tarif sebesar $4 \%$ begitu juga dengan penyedia jasa yang tidak memiliki Nomor Pokok Wajib Pajak (NPWP) namun dikenakan tarif sebesar 2\%. Setelah dianalisis kembali ternyata didapati kurang telitinya pihak bendahara dalam melakukan perhitungan. Berikut tarif yang dikenakan pada Pajak Penghasilan Pasal 23 atas jasa:

ber-NPWP:

PPh Pasal $23=2 \%$ x Jumlah Penghasilan Bruto

Tidak ber-NPWP:

PPh Pasal $23=4 \% \times$ Jumlah Penghasilan Bruto 
Berikut contoh kasus perhitungan:

1. Jumlah Penghasilan Bruto

2. PPh Pasal 23 yang dipotong:
1) ber-NPWP
2) tidak ber-NPWP

3. Pajak terutang yang disetor ke kas Negara:
1) ber-NPWP
2) tidak ber-NPWP
: Rp. 40.000
:Rp. 80.000

4. Jumlah yang dibayarkan ke pemberi jasa

1) ber-NPWP

: Rp. 1.960 .000

2) tidak ber-NPWP

Keterangan :
: Rp. 2.000.000

:Rp. $40.000=2 \%$ x Rp. 2.000 .000

:Rp. $80.000=4 \%$ x Rp. 2.000 .000
(Rp. 2.000.000 - Rp. 40.000)

: Rp. 1.920 .000

(Rp. 2.000.000 - Rp. 80.000)

Dari contoh pemotongan diatas, diketahui jumlah penghasilan bruto atas jasa sebesar Rp. 2.000.000. Pajak terutang yang disetor ke kas Negara apabila ber-NPWP sebesar Rp. 40.000 dengan tarif 2\% sedangkan apabila tidak ber-NPWP sebesar Rp. 80.000 dengan tarif $4 \%$. Jumlah yang harus dibayarkan ke pemberi jasa apabila ber-NPWP sebesar Rp. 1.960.000 sedangkan apabila tidak ber-NPWP sebesar Rp. 1.920.000.

Melalui Withholding System pihak pemotong adalah pihak-pihak yang membayarkan penghasilan. Pihak ketiga adalah pihak bendahara yang bertanggungjawab atas kewajiban perpajakannya. Hal ini membuat pihak bendahara harus mengisi segala data secara benar, jelas dan lengkap. Pihak Pemotong yang melakukan pemotongan yang ada diperusahaan sudah sesuai dengan Ketentuan Undang-Undang Pajak Penghasilan Pasal 23.

Analisis Penyetoran dan Pelaporan. Berdasarkan hasil penyetoran dan pelaporan pada bagian sebelumnya tidak terdapat kesalahan dalam penyetoran dan pelaporan Pajak Penghasilan Pasal 23 selama Tahun 2017. Hasil penyetoran dan pelaporan sudah sesuai dengan prosedur dalam Ketentuan Undang-Undang Pajak Penghasilan Pasal 23 yaitu sebagai berikut:

Penyetoran. Prosedur dalam penyetoran yaitu sebagai berikut:

1. Pihak Bendahara menyiapkan dan mengisi Surat Setoran Pajak (SSP) secara benar, jelas dan lengkap.

2. Pihak Bendahara membawa Surat Setoran Pajak (SSP) dan Daftar Bukti Pemotongan untuk dilakukan penyetoran ke Bank yang ditunjuk oleh Menteri Keuangan.

3. Pihak Bank yang ditunjuk oleh Menteri Keuangan akan memberikan Bukti Penyetoran sebagai bukti bahwa pihak pemotong telah melakukan penyetoran.

Untuk Surat Setoran Pajak (SSP) lembar ke-1 untuk Arsip Wajib Pajak, lembar ke-2 untuk Kantor Pelayanan Perbendaharaan Negara, lembar ke-3 untuk dilaporkan ke Kantor Pelayanan Pajak dan lembar ke-4 untuk Bank Persepsi/Kantor Pos dan Giro. Dalam hal penyetoran Pajak Penghasilan Pasal 23 jangka waktu yang telah ditetapkan oleh Pemerintah harus disetor paling lama tanggal 10 bulan berikutnya.

Pelaporan. Prosedur dalam pelaporan Pajak Penghasilan Pasal 23 yaitu sebagai berikut:

1. Pihak Bendahara menyiapkan dan mengisi Surat Pemberitahuan (SPT) secara benar, jelas dan lengkap sesuai dengan Surat Setoran Pajak (SSP).

2. Pihak Bendahara melakukan pelaporan ke Kantor Pelayanan Pajak (KPP) dengan melampirkan Surat Pemberitahuan (SPT), Surat Setoran Pajak (SSP), Daftar Bukti Pemotongan dan Bukti Pemotongan. 
3. Pihak Kantor Pelayanan Pajak (KPP) akan memberikan Bukti Pelaporan sebagai bukti bahwa pihak pemotong telah melakukan pelaporan.

Dalam hal pelaporan Pajak Penghasilan Pasal 23 jangka waktu yang telah ditetapkan oleh

Pemerintah harus disetor paling lama tanggal 20 bulan berikutnya.

\section{KESIMPULAN DAN SARAN}

\subsection{Kesimpulan}

Berdasarkan hasil pembahasan pada bagian sebelumnya dapat disimpulkan:

1. Objek-Objek Pajak Penghasilan Pasal 23 semuanya telah diterapkan sesuai dengan Ketentuan Undang-Undang Pajak Penghasilan Pasal 23.

2. Proses Perhitungan setelah diuji, ada beberapa objek yang masih belum sesuai dengan Ketentuan Undang-Undang Pajak Penghasilan Pasal 23.

3. Proses Penyetoran dan Pelaporan sudah sesuai dengan Ketentuan Undang-Undang Pajak Penghasilan Pasal 23.

Dengan demikian dapat dikatakan seluruh proses Pajak Penghasilan Pasal 23 telah dilakukan sebagaimana mestinya.

\subsection{Saran}

Saran dari penelitian ini adalah sebagai berikut:

1. Dalam prosedur pemotongan sebaiknya pihak bendahara harus lebih teliti dalam pengenaan tarif, serta sesuai dengan Undang-Undang Perpajakan yang berlaku.

2. Dalam prosedur penyetoran dan pelaporan pajak terutangnya pihak perusahaan sudah sesuai dengan Undang-Undang Perpajakan yang berlaku, diharapkan pihak perusahaan tetap mempertahankan kedisiplinan dalam prosedur penyetoran dan pelaporannya.

3. Diharapkan pihak bendahara yang melakukan prosedur pemotongan, penyetoran dan pelaporan dan pegawai perusahaan dibekali dengan pengetahuan mengenai perpajakan sesuai dengan Undang-Undang Perpajakan yang berlaku.

\section{DAFTAR PUSTAKA}

Hery. 2016. PPh \& PPN Ditinjau dari Aspek Perpajakan maupun Akuntansi. Jakarta: Penerbit PT Grasindo.

Lubis, Irsan. 2015. Mahir Akuntansi Pajak Terapan Berbasis Standar Akuntansi \& Ketentuan Pajak Terbaru. Yogyakarta: Penerbit CV Andi Offset.

Mardiasmo. 2018. Perpajakan Edisi Terbaru 2018. Yogyakarta: Penerbit CV Andi Offset.

Muljono, Djoko dan Baruni Wicaksono. 2009. Akuntansi Pajak Lanjutan. Yogyakarta: Penerbit CV Andi Offset.

Peraturan Pemerintah Nomor 9 Tahun 1963 tentang Pembelanjaan Pegawai Negeri. Lembaran Negara Republik Indonesia Tahun 1963 Nomor 14, Indonesia.

Peraturan Pemerintah Nomor 10 Tahun 1963 tentang Tabungan Asuransi dan Pegawai Negeri. Lembaran Negara Republik Indonesia Tahun 1963 Nomor 15, Indonesia.

Redaksi Sinar Grafika. 2017. Seri Peraturan Perpajakan: Undang-Undang Pajak Penghasilan. Jakarta: Penerbit Sinar Grafika.

Resmi, Siti. 2014. Perpajakan: Teori dan Kasus. Jakarta: Penerbit Salemba Empat.

Subadriyah. 2017. Pajak Penghasilan. Yogyakarta: Penerbit Pustaka Pelajar.

Suwardjono. 2009. Akuntansi Pengantar. Yogyakarta: Penerbit BPFE.

Undang-Undang Nomor 7 Tahun 1983 tentang Pajak Penghasilan sebagaimana telah diubah dengan Undang-Undang Nomor 36 Tahun 2008. Lembaran Negara Republik Indonesia Tahun 2008 Nomor 133, Indonesia. 
Undang-Undang Republik Indonesia Nomor 11 Tahun 1969 tentang Pensiun Pegawai dan Pensiun Janda/Duda Pegawai. Lembaran Negara Republik Indonesia Tahun 1969 Nomor 42, Indonesia.

Undang-Undang Republik Indonesia Nomor 6 Tahun 1983 tentang Ketentuan Umum dan Tata Cara Perpajakan sebagaimana telah diubah dengan Undang-Undang Republik Indonesia Nomor 16 Tahun 2009. Lembaran Negara Republik Indonesia Tahun 2009 Nomor 62, Indonesia.

Undang-Undang Republik Indonesia Nomor 11 Tahun 1992 tentang Dana Pensiun. Lembaran Negara Republik Indonesia Tahun 1992 Nomor 37, Indonesia.

Undang-Undang Republik Indonesia Nomor 40 Tahun 2004 tentang Sistem Jaminan Sosial Nasional. Lembaran Negara Republik Indonesia Tahun 2004 Nomor 4456, Indonesia. 